\title{
Towards understanding the role of ectomycorrhizal fungi in forest phosphorus cycling : a modelling approach
}

\author{
Michiel F. Bortier1,*, Enrique Andivia² ${ }^{2}$ José G. Genon ${ }^{3}$, Tine Grebenc ${ }^{4}$, \\ Gaby Deckmyn ${ }^{1}$
}

${ }^{1}$ Centre of Excellence PLECO (Plant and Vegetation Ecology), Department of Biology, University of Antwerpen, Universiteitsplein 1, 2610 Antwerpen, Belgium

${ }^{2}$ Forest Ecology and Restoration group, Departamento de Ciencias de la vida, Universidad de Alcalá, Apdo. 20, Campus Universitario, 28805 Alcalá de Henares, Madrid, Spain

${ }^{3}$ Earth and Life Institute, Environmental Sciences, Université catholique de Louvain, Croix du Sud 2 L7.05.09, 1348 Louvain-la-Neuve, Belgium

${ }^{4}$ Slovenian Forestry Institute, Večna pot 2, SI-1000 Ljubljana, Slovenia

\begin{abstract}
Many studies have shown the importance of ectomycorrhizal fungi (EM) in forests both for nutrient availability and for carbon (C) and nutrient cycling in the soil. Yet so far they are not incorporated in forest ecosystem growth and yield models. Recent research suggests phosphorus (P) shortage could be a major constraints to forest productivity in the future. For a realistic simulation of future forest ecosystem functioning, inclusion of detailed soil P cycling and the trees-EM interaction is necessary. We developed a full ecosystem $\mathrm{P}$ model that simulates $\mathrm{P}$ uptake by roots and EM, allocation within trees, physiological deficiency effects on $\mathrm{C}$ assimilation and allocation, release through litter decomposition, coupled with water, $\mathrm{C}$ and nitrogen $(\mathrm{N})$ fluxes accounted for in the mechanistic forest stand model ANAFORE. Our results confirm the importance of incorporating EM in forest ecosystem models and suggest that the lack of incorporation of $\mathrm{P}$ in models may result in an under- or overestimation of forest growth. This new model has the potential of being used to assess the response of trees and/or stands to nutrient availability under different climate and management scenarios. With the current parameterization it is functional as a scientific research tool to investigate hypotheses.
\end{abstract}

Key words: nutrient cycling; mechanistic model; pine forest; ectomycorrhizal fungi; phosphorus

Editor: Bohdan Konôpka

\section{Introduction}

Forest models can be useful tools not only to predict forest productivity but also (and often mainly) to increase our understanding of forest ecosystem functioning. Models allow us to investigate hypothesis concerning processes and present an opportunity to run virtual experiments impossible to run at a forest scale in a reasonable timescale. To investigate and understand how changes in climate and management affect the forest ecosystem it is important that forest models take into account the main drivers. Recent findings in soil nutrient cycling and the interaction between trees and mycorrhizal fungi are not yet implemented into most forest models (Gérard et al. 2017), which limits their predictive capacity concerning some key issues, such as the nutritional status of trees under environmental changes (Hinsinger et al. 2011; Deckmyn et al. 2014).
Although increases in temperate and boreal forest productivity have been evidenced in Europe over the last decades the extent and continuity of the atmospheric $\mathrm{CO}_{2}$ enrichment effect critically depends on nutrient availability (Nowak et al. 2004; Norby et al. 2010; FernándezMartínez et al. 2014). The sustainability of this growth increase is questioned in areas of sustained high $\mathrm{N}$ deposition, such as northwestern Europe (de Vries et al. 2009). This is particularly true for many forests located on acidic soils, where $P$ has been recognized as potential key limiting nutrient in that context (Braun et al. 2010; Vitousek et al.2010), leading to deterioration of tree vitality (Jonard et al. 2012; Jonard et al. 2015). Moreover, forest yield is not the only important issue as other key forest functions including $\mathrm{C}$ storage and stabilization of nutrients in the soil are increasingly seen as key factors in sustainable forest management (Toman \& Ashton 1996). 
While significant progress has been made in developing mechanistic models simulating the $\mathrm{C}$ and $\mathrm{N}$ cycles in the past decades, including the cycling of $\mathrm{P}$ has received less attention (Vereecken et al. 2016), except for agricultural models (Landsberg et al. 1991; Probert et al. 2000). Recently mechanistic models have been developed that include P in the litter and SOM pools (Runyan \& D'Odorico 2012), though more often the representation of P uptake is simple and empirical. Most existing stand models empirically compare soil $\mathrm{P}$ availability with tree demand and reduce growth to available nutrient levels in case of limitation. The mineralization of organic matter is described as a function of environmental factors and litter quality only, based on decay rates, while microbial roles remain inherently incorporated and fixed in used constants.

Moreover, EM are on the whole rarely included in ecosystem models, even though hyphae extension beyond root depletion zones and their efficient absorption kinetics are vital in simulating $\mathrm{P}$ uptake at low soil concentrations (Read \& Perez-Moreno 2003; Read et al. 2004; Deckmyn et al. 2014). In the field of EM and arbuscular mycorrhizae (AM) modeling, quite a number of models have been developed and applied showing the importance of the EM fungi and how they trade nutrients for carbon with the plant. Recently, a few of these have been linked to ecosystem models (some only for $\mathrm{N}$-uptake) (Orwin et al. 2011; Meyer et al. 2012; Franklin et al. 2014). The major drawback of conventional models excluding mycorrhizae is that uptake of nutrients is only possible from mineralized sources, while in reality EM fungi are able to extract nutrients from organic sources and these nutrients become available to the host trees (Lindahl \& Tunlid 2014). The lack of consideration of the P cycling, the role of mycorrhizae and the ability of plants to react to nutrient deficiency in forest ecosystem models may result in an overestimation of plant growth, and therefore failure to accurately predict forest dynamics under climate change scenarios (Fernández-Martínez et al. 2014; Jonard et al. 2015). However, including $P$ without a realistic simulation of the interaction between EM and trees can lead to overestimation of P-limitation, as very little mineral $\mathrm{P}$ is present in the soil solution. Mycorrhizae also significantly affect soil aggregation (Zhenh et al. 2014). It is within this context that a complete process-based description of the P cycling and its limiting effect on tree growth in forest models becomes crucial in order to understand the magnitude and direction of forest stands response to future changes and how management can affect these.

In this paper, we describe a new process-based model that details the $\mathrm{P}$ cycle in forest ecosystems. This includes element fluxes such as uptake, storage and transfer by EM; uptake by fine roots, allocation and translocation within trees, and the effect of $\mathrm{P}$ deficiency on essential plant functions such as photosynthesis, growth and biomass allocation. This process-based model is integrated into the mechanistic forest ecosystem model ANAFORE (ANAlysis of FORest Ecosystems), in which this new module interacts with other existing modules such as the growth, C, N and soil modules (Deckmyn et al. 2008; Deckmyn et al. 2011). In order to show the application of this new module, the model is parameterized for the Scots pine (Pinus sylvestris L.) forest "De Inslag" in Belgium. Our aim is to provide a modeling framework to simulate $\mathrm{P}$ cycling in forest ecosystem models. In addition to this model description, we quantify the main pools and fluxes in the new model with emphasis on the role of mycorrhizae in the uptake of P in low soil concentrations. Furthermore, we demonstrate the simulation of seasonal changes in $\mathrm{P}$ allocation within the trees and the shortage effects thereof on forest growth. We also analyze the model sensitivity to mycorrhizal parameters to investigate how important EM differentiation is to the overall results and finally we show how small changes in management such as leaving branches on the site at harvest can affect the soil nutritional status.

\section{Materials and methods}

A new module describing the cycling of elements in forest ecosystems is integrated into the mechanistic forest ecosystem model ANAFORE (Deckmyn et al. 2008). Despite the fact that this new module is formulated in general terms, making it applicable for many elements (both nutrients and nonessential elements, here generally described as $X$ ), in this paper we limit ourselves to its application for P. Briefly, the previous ANAFORE model simulates stand $\mathrm{C}$, water and $\mathrm{N}$ fluxes, tree growth, and wood tissue development by following a bottom-up approach: leaf level processes (e.g. photosynthesis and transpiration) are simulated at a half-hourly time step and implemented into a daily-operating single tree architecture and $\mathrm{C}$ allocation module (see Deckmyn et al. (2008) for a full description). ANAFORE was then improved by including a soil module that mechanistically simulates the organic material decay dynamics by three microorganism functional groups: bacteria, mycorrhizal fungi and non-mycorrhizal fungi (see Deckmyn et al. (2011) for a full description). This basic ANAFORE soil model is different from most existing models in that decay rates are not a function only of litter quality and environment but are simulated as an active process by competing bacteria and fungi.

\subsection{Model description}

\subsubsection{Model pools}

Three different essential pool types are considered in the model: soil pools, microorganism pools and tree pools (Fig. 1). The soil system is built up similarly to that of the main ANAFORE model (Deckmyn et al. 2011). Briefly, it consists of up to ten mineral horizons, each subdivided into layers (in equations referred to with the subscript letter $i$ ) with a fixed thickness of $1-2 \mathrm{~cm}$, and a surface 


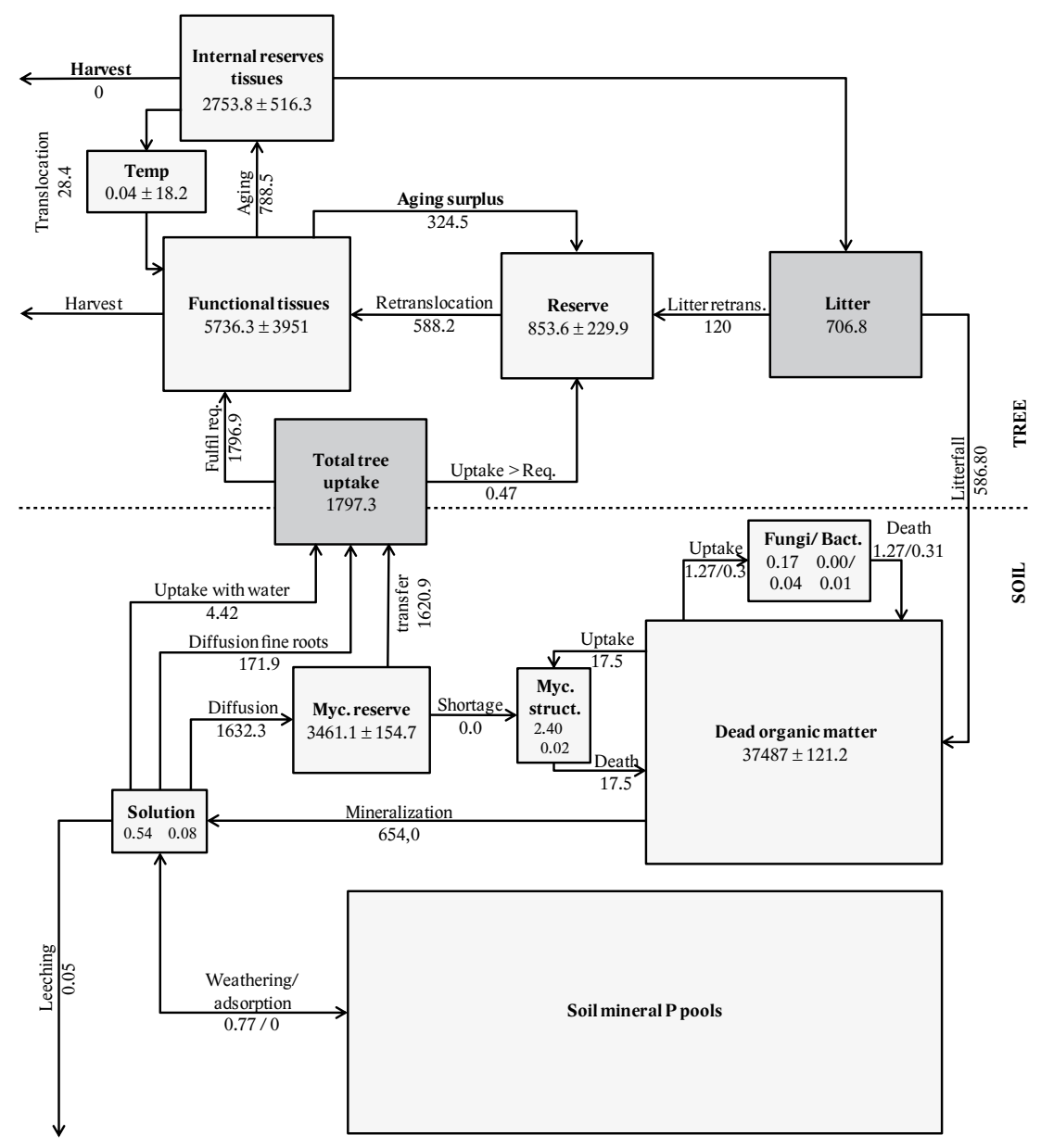

Fig. 1. Relational diagram describing the pools (light grey squares; $\mathrm{mg} \mathrm{P} \mathrm{m}^{-2}$ ) and the fluxes (arrows and dark grey squares; $\mathrm{mg} \mathrm{P} \mathrm{m}^{-2}$ year-1 $^{-1}$ considered in the forest ecosystem $\mathrm{P}$ cycling model. Average values over all 15 parameter sets are shown for the 20 th year of the standard simulation, i.e. simulating actual environmental conditions. Errors show variations on the daily average pool sizes throughout the year.

organic layer that lies on top of the mineral layers and has a variable thickness depending on the amount and density of litter biomass. Every layer has a litter pool and every mineral layer has mineral $P$ pools.

The mineral $\mathrm{P}$ pools are derived from a conceptual model widely and for a long time used in agriculture, and more recently applied to forest soils. It distinguishes a labile (Plab), an active (Pact) and a stable pool (Pstab) (fast-, medium- and slowly-reacting respectively), plus a P-containing primary mineral pool (Pprim) (Dzotsi et al. 2010; Jones et al. 1984; Parton et al. 1988). The labile P pool itself includes a solution (Psolu) and an adsorbed (Pads) pool, which are considered to be in equilibrium.

The litter pool in every soil layer is further divided into leaf (leaf, only the organic layer) and wood (including roots) litter of the following size ranks: fine (size $<2$ $\mathrm{cm})($ Fin $)$, small (size 2-10 cm) $(\mathrm{Sm})$ and coarse (size $>10 \mathrm{~cm})(\mathrm{Co})$. Each of these litter pools, and all derived pools, are divided into an accessible $(A)$, cellulose $(\mathrm{Cel})$ and recalcitrant $(R)$ fraction. In addition to the $\mathrm{C}$ and $\mathrm{N}$ content of these pools, as described in the main ANAFORE model, we add the content of other elements $(X)$, although the following description only details what is applicable to $\mathrm{P}$ (Table A1). This organic material is then further decomposed into fragmented pools, after which it can be humified by mycorrhizae, fungi and bacteria, and can form micro- and macroaggregates (Deckmyn et al. 2008). Hereafter there is a distinction between model equations that are applicable to all elements, equations applicable only to nutrients and equations specifically concerning P.

Both fungi and bacteria contain only one element pool each. In the case of mycorrhizae however, we consider two element pool types: (i) one mycorrhizal reserve pool (Xmyc,res) in which elements absorbed from the soil solution or from organic matter decay are stored and from which elements can be transferred to the host plants, and (ii) a mycorrhizal structural pool (Xmyc,struct). Unlike in the structural pools, the element content of the mycorrhizal reserve pool is unlimited and therefore not confined by the amount of mycorrhizal biomass. Only the element surplus in the mycorrhizal reserve pool can be transferred to trees.

Trees are divided in the following tissue pools: current year leaves or needles $(l 0)$, old leaves or needles of 
evergreen species (l1), dead bark of branches (brabark) and stem (stembark), current year sapwood of branches (braO), stem (stem0) and coarse roots ( $\mathrm{cr} O)$, old sapwood of branches (bra1), stem (stem1) and coarse roots (cr1), heartwood of branches (braheart), stem (stemheart) and coarse roots (crheart), fine roots ( fr) and fruits (fruits). These element pools are broadly classified into two groups: (i) the functional tissue pools, that require nutrients for growth, comprising current year leaves or needles and sapwood, bark, and fruits; and (ii) the internal reserves tissue pools, comprising old leaves or needles and old sapwood, whose nutrient content can be depleted in case of nutrient deficiency. Furthermore, heartwood does not belong to either of these two categories, since it consists of dead tissue from which nutrients are retranslocated before its formation (Meerts 2002). In addition to the $\mathrm{N}$ content and concentration provided by the main ANAFORE model, all tissue pools are characterized by their carbon content $\left(C_{\text {pool }}\right)$, which is also provided by ANAFORE, element content $\left(X_{\text {pool }}\right)$ and the derived element concentration on carbon content basis $\left([X]_{\text {pool }}\right)$. In addition to the actual element concentration in the pools, the deficient $\left([X]_{\text {def,pool }}\right)$, optimal $\left([X]_{\text {opt,pool }}\right)$ and maximum $\left([X]_{\text {max,pool }}\right)$ concentrations are defined for each pool as input parameters. Besides these tissue pools we define two nonphysical pools at tree level. The first is the reserve pool (res) in which retranslocation from litterfall and element uptake over requirements are stored and which is only defined by its current and maximum element content ( $X_{\text {res }}$ and $X_{\text {res,max }}$ respectively). Nutrients stored in this pool are allocated to functional tissue pools in case of deficiency. The second is the temporary pool (tem) in which nutrients from internal reserves tissue pools are translocated before being distributed among functional tissue pools in case of severe nutrient deficiency that cannot be offset solely by the reserve pool (see also 2.1.5).

\subsubsection{Mycorrhizal model}

The ANAFORE mycorrhizal model can be used to describe both arbuscular and EM fungi, but the parameterization used here is specific for EM. Compared to the previous ANAFORE version (Deckmyn et al. 2008), the description of the EM fungi is further refined based on recent findings (Deckmyn et al. 2014). In the current version, user-defined parameters divide the EM biomass in fractions of rhizomorphs, hyphae and EM root tips, which have different turnover times. Furthermore the parameter "extension" $(x)$ describes how far from the root tip the hyphal network reaches, so different EM types can be described (see also 2.1.4 and Table 1).

As in the previous version, the capacity of EM to degrade organic compounds is user defined and can be changed to describe a specific EM community (if enough data are known). Moreover, EM fungi can degrade complex compounds with low energy content by using plantderived energy, to mineralize the nutrients from these compounds (Shah et al. 2016).

The interaction between the EM and the host trees is simple at this stage: a fixed fraction of the $\mathrm{C}$ allocated to the roots by the tree is available to the EM. Storage nutrients from the EM are available to the host plant if there is demand through a Michaelis-Menten kinetic, but under nutrient shortage (not enough structural nutrients for the EM fungi) the EM will not partition any to the tree (see also 2.1.4).

\subsubsection{Model fluxes}

For each specific element a series of inputs to and outputs from the system are considered. In the specific case of $\mathrm{P}$ we considered a single source in the system, i.e. weathering, and two pathways though which P is lost: leaching from the dissolved fraction in the lowest mineral layer, and tree harvesting (Fig. 1).

$\mathrm{P}$ is released in the system through weathering of the soil mineral $P$ pools. The fluxes between the primary, labile, stable and active $\mathrm{P}$ pools are proportional to the pool considered and described by five parameters: $K p 1$ from primary to labile, $K p 2$ from labile to active, $K p 3$ from active to labile, $K p 4$ from active to stable, $K p 5$ from stable to active. The weathering flux is the net result of these interactions. Several options are proposed to set the values of the $K p 1-5$ parameters: the original equations from Jones et al. (1984) and Dzotsi et al. (2010), with an additional soil $P$ reactivity parameter, the values given in Parton et al. (1988). In the labile P pool, the equilibrium between the solution and adsorbed $\mathrm{P}$ is described by a Langmuir isotherm with a maximal sorption Pmax and a Langmuir constant KpLang. A further refinement allows

Table 1. Sensitivity of the model to variations in EM parameters, harvesting or leaving branches at harvest, variations in fine root (FR) turnover and thickness.

\begin{tabular}{|c|c|c|c|c|c|c|}
\hline Variable & $\begin{array}{l}\text { Soil C } \\
\mathrm{kg} \mathrm{ha}^{-1}\end{array}$ & $\begin{array}{l}\text { SoilP } \\
\text { gha }^{-1}\end{array}$ & $\begin{array}{c}\text { Tree stems } \\
\text { tha }^{-1}\end{array}$ & $\begin{array}{c}\mathrm{EM} \\
\mathrm{g} \mathrm{m}^{-2}\end{array}$ & $\mathrm{q}_{\mathrm{r}-\mathrm{sh}}$ & $\begin{array}{c}\text { Tree height } \\
\mathrm{m}\end{array}$ \\
\hline Best fit parameter set & 29.34 & 37.9 & 210.9 & 3.31 & 0.26 & 23.88 \\
\hline No EM & 24.40 & 28.0 & 120.8 & 3.09 & 0.32 & 16.03 \\
\hline EM $10 \%$ rhizomorphs & 29.40 & 37.8 & 209.4 & 3.26 & 0.26 & 23.88 \\
\hline EM 50\% rhizomorphs & 29.33 & 37.5 & 211.1 & 3.31 & 0.26 & 23.88 \\
\hline EM Extension $0.2 \mathrm{~m}$ & 29.33 & 38.1 & 211.1 & 3.31 & 0.26 & 23.88 \\
\hline EM Extension $0.5 \mathrm{~m}$ & 29.34 & 38.2 & 211.1 & 3.31 & 0.26 & 23.88 \\
\hline Leave branches & 29.25 & 38.4 & 208.1 & 3.32 & 0.26 & 23.93 \\
\hline Remove all litter & 29.29 & 37.9 & 210.5 & 3.31 & 0.26 & 23.88 \\
\hline FR radius $1 \mathrm{~mm}$ & 29.18 & 37.7 & 208.3 & 3.38 & 0.25 & 23.93 \\
\hline FR turnover & 30.96 & 40.1 & 198.5 & 3.74 & 0.26 & 23.33 \\
\hline
\end{tabular}


accounting for the effect of $\mathrm{pH}$ on $\mathrm{P}$ sorption by making Pmax linearly dependent on pH (Jeppu \& Clement 2012); it was not used in the present exercise.

We consider that elements in solution are absorbed by trees through three pathways (Fig. 1) (see also 2.1.4). First, fine roots absorb solutes per soil layer through a combination of diffusion and active transport (Xup,fr, dif $(i)$ ), hereinafter referred to as 'diffusion'. In addition dissolved elements are absorbed through the fine roots along with water uptake (Xup, fr,sol(i)). Finally, part of the elements taken up by the mycorrhizae is transferred from the mycorrhizal reserve pool to the host trees (Xtrans). Then, the absorbed element amount is allocated to the different tissue pools according to their requirements and/or nutrients are remobilized internally in case of deficiency (see also 2.1.5).

The amount of an element that is lost from each tissue pool through litterfall (Xlit,pool) is determined according to the litter biomass, yet a fraction of this amount is retranslocated before litterfall occurs (Xretran_in,pool) and allocated to the reserve pool (Fig. 1). The element contents of litter from needles, branches and stems is then added to the litter pools in the surface organic layer, while litter from roots is added to the litter pools of both the organic and the mineral soil layers. Elements are released from the litter pools in the soil system through decomposition, either in a direct pathway from organic matter to the microorganisms or through an indirect pathway to the soil solution (see Deckmyn et al. (2011) for a full explanation).

\subsubsection{Element uptake}

As we stressed before, we consider three pathways along which elements are taken up from the soil. Potential element uptake at tree level is then calculated as the sum of these three pathways: diffusion in mycorrhizae and fine roots, absorption along with water through fine roots and element transfer from the mycorrhizae to the host plant. Defining the soil cylinder exploited by mycorrhizae and fine roots is the first step in element uptake calculations. We assume as a starting point that every tree occupies areas of equal sizes both above and below ground between the surrounding trees (Zinke 1962). However, the horizontal area of the soil layer in which fine roots and mycorrhizae are located $(S s(i))$ decreases with soil depth, showing a typical inverted cone distribution (Deckmyn et al. 2008). In order to include the effect of the size of the influence zone, a correction factor $(f z)$ is determined for each soil layer. When the surface of the influence zone is the same size as the surface of the tree canopy, which is calculated from the canopy radius ( rcrown), $f z$ is equal to one; otherwise it is smaller, since a smaller influence area results in a decreased element uptake. The inclusion of this correction factor is therefore particularly important in the case of non-mobile elements such as P, which is why the element-specific soil to absorption surface resistance
$(R s-p o o l, X)$ is also included in the formula. The correction factor for fine roots $(f z, f r(i))$ is then calculated as in equation [1].

$$
f_{z, f r(i)}=\frac{1-\left(-S_{s(i)}+\pi r_{c r o w n}^{2}\right)}{R_{s-f r, x}-S_{s(i)}+\pi r_{\text {crown }}^{2}}
$$

In the case of the mycorrhizal correction factor $(f z, m y c(i))$ the radius and thus the surface of the influence zone as defined by the fine roots is extended by the mycorrhizal extension $(x)$.

Uptake processes through diffusion are described per soil layer based on the absorption surface of either mycorrhizae $(U A, m y c(i))$ or fine roots $(U A, f r(i))$ as is shown in equation [2]. Both absorption surfaces are calculated based on the fine root or mycorrhizal $\mathrm{C}$ content per soil layer (Cpool(i)), the average fine root or mycorrhizal density ( $\rho p o o l)$ and the average fine root or mycorrhizae radius $\left(r_{p o o l}\right)$.

$$
U_{A, p o o l(i)}=\frac{C_{\text {pool }(i)}}{\rho_{\text {pool }}+r_{\text {pool }}}
$$

First, half-hourly element uptake through diffusion by mycorrhizae $\left(X_{u p, m y c(i)}\right)$ and fine roots $\left(X_{u p, f r}, \operatorname{dif}(i)\right)$ is calculated per layer according to the Michaelis-Menten type equation [3] (Barber 1995). These equations depend on three element and organism specific Michaelis-Menten parameters: the maximum absorption rate per absorption surface area (Imax,pool), the Michaelis constant $\left(K_{m, p o o l}\right)$, which is the mineral element concentration in the soil solution at which the uptake rate reaches half of the maximum absorption rate, and the element concentration in the soil solution below which element absorption does not occur (Clim,pool). These parameters are different for mycorrhizae and fine roots (Colpaert et al. 1999; Schnepf \& Roose 2006; Van Tichelen \& Colpaert 2000). The uptake also depends on the dissolved concentration of the element in the soil layer $\left(c_{p(i)}\right)$, which is calculated as the soluble fraction of the element in the layer $\left(X_{p(i)}\right)$ divided by the water content of the layer $(\theta s(i))$, which is provided by the ANAFORE soil module.

$$
X_{\text {up,pool }(i)}=\frac{f_{z, \text { pool }(i)} U_{A, p o o l(i) I_{\text {max }, \text { oool }}}\left(c_{p(i)}-c_{\text {lim,pool }}\right)}{K_{m, \text { pool }}+\left(c_{p(i)}-c_{\text {lim,pool }}\right)}
$$

Next, absorption of elements along with water absorption by fine roots $\left(X_{u p, f r, s o l(i)}\right)$ is also calculated half-hourly in each soil layer and only when water uptake $\left(W_{u p(i)}\right)$ is positive, as performed in equation [4].

$$
X_{u p, f r, s o l(i)}=\frac{W_{u p(i)}}{\left(\theta_{s(i)}+W_{u p(i)}\right)} c_{p(i)}
$$

Finally, element transfer from the mycorrhizae to the host plant ( $X_{\text {trans }}$ ) as described in equation [5] occurs if the element concentration in the mycorrhizal reserve pool ([X]myc,res), calculated as the element content of the mycorrhizal reserve pool divided by the sum of the mycorrhizal biomass in all soil layers, is greater than 
a threshold concentration ([X]lim,trans). Transfer is described based on a Michaelis-Menten type equation analogous to that describing element uptake through diffusion, with the main difference that transfer varies according to the internal element concentration in the mycorrhizae rather than the soil concentration.

$$
X_{\text {trans }}=\frac{I_{\text {max }, \text { trans }}\left([X]_{\text {myc,res }}-[X]_{\text {lim,trans }}\right)}{K_{m, \text { trans }}+\left([X]_{\text {myc,res }}-[X]_{\text {lim,trans }}\right)}
$$

Once uptake by mycorrhizae and fine roots is calculated, element content of the corresponding soil layers and fraction are reduced accordingly. Then, the total halfhourly potential uptake at tree level is calculated as the sum of the uptake through diffusion by fine roots, transfer of elements from mycorrhizae and the elements taken up with water uptake in each soil layer. The daily potential uptake at tree level $(X u p, T)$ consists of the daily sum of the half-hourly potential element absorption.

\subsubsection{Element status}

The amount of elements demanded by trees is a central part of the element module because it determines the nutritional status of trees and may limit element uptake. Regarding this, we define two levels of element needs: requirement and demand. At tree level, element requirement $(X r e q, T)$ is the amount of a specific element needed to support new growth at optimal concentration and to maintain the functionality of all tissues, i.e. keep all tissues at optimal concentrations, as defined in equation [6].

$X_{\text {req,T }}=\sum\left[\left(\Delta C_{\text {pool }} \times[X]_{\text {opt }, \text { pool }}\right)+C_{\text {pool }}\left([X]_{\text {opt }, \text { pool }}-[X]_{\text {pool }}\right][6]\right.$
Tree nutrient demand $(X d e m)$ is the amount of a specific element needed to not only meet growth requirements but also to fill the reserve pool, as described by equation [7].

$$
X_{\text {dem }}=X_{\text {req,T }}+X_{\text {res,max }}-X_{\text {res }}
$$

The maximum element content of the reserves pool (Xres, max) is the maximum amount of elements that can be stored in this pool, as obtained through equation [8]. This is physically limited to the amount of the element that corresponds to maximum concentrations in all tree tissue pools.

$$
X_{\text {max }, \text { res }}=\sum C_{\text {pool }}\left([X]_{\text {max }, \text { pool }}-[X]_{\text {opt,pool }}\right)
$$

Five situations are considered according to the balance between on one hand element supply (element uptake and tree element reserves) and on the other hand the element requirement and demand by the tree (Fig. 2). In situation 1 , the daily potential nutrient uptake exceeds the demand so the uptake is limited to the demand and the excess of elements is returned to the soil solution and mycorrhizal reserve pool proportionally to the contribution of the absorption mechanisms to the total potential uptake. In this case all tissue pools are at optimum conditions and the reserve pool is filled to maximum. In situation 2 , the uptake is greater than requirements but lower than the demand. Accordingly, all tissue pools grow at optimal conditions and the rest of elements are allocated to the reserve pool. In situation 3, element uptake is lower than the demand and, therefore, retranslocation occurs from the reserve pool to the tissues pools, which will grow at optimal concentrations. In situation 4 element uptake is also lower than demand but the elements stored in the

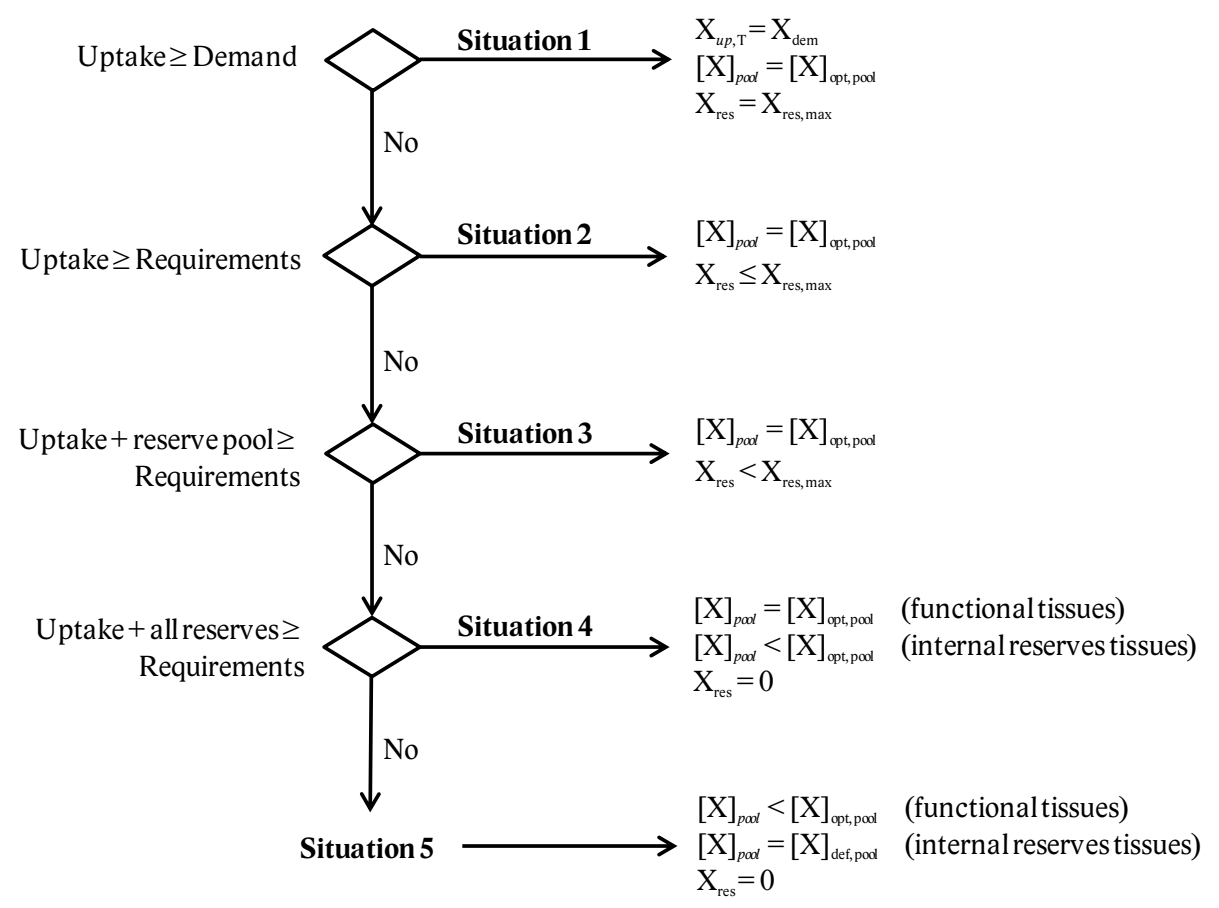

Fig. 2. Decision diagram describing the different model situations according to tree nutritional status. 
reserve pool are not sufficient to meet the requirements. In this case, requirements are met by translocating elements from the internal reserves tissue pools, those tissue pools that can be depleted in case of shortage, and allocating them to the temporary pool, from where the remobilized quantity is redistributed among the functional tissue pools at the same time step. The maximum amount of nutrients that can be remobilized from these internal reserves tissue pools in one day (Xtem) (old leaves/needles and sapwood) is calculated according to equation [9].

$$
X_{\text {tem }}=f_{x, \text { temp }} \sum C_{\text {pool }}\left([X]_{o p t, p o o l}-[X]_{d e f, p o o l}\right)
$$

where $f x$,temp is a parameter that limits the amount of element that can be mobilized at each model time step from old tissues. The last situation (situation 5) implies that, in spite of all nutrients being taken from the reserves pool at tree level and the internal reserves tissue pools, the amount of nutrients supplied is not enough to achieve optimal concentrations in the functional tissue pools.

\subsubsection{Phosphorus shortage effect on trees}

In general the effect of element shortage, or toxicity in the case of toxic elements such as pollutants, is implemented in the model according to the degree of the shortage or toxicity. In the case of essential elements, i.e. nutrients, these effects are implemented as the modification of biomass allocation and the limitation of photosynthesis and growth. Here we explain the specific effect for $\mathrm{P}$ shortage. The first effect is the modification of $\mathrm{C}$ allocation by increasing the root to shoot growth ratio $\left(q_{r \text {-sh,norm }}\right)$ up to a maximum ratio ( $\left.q_{r \text {-sh,max }}\right)$ when the element uptake is lower than the growth requirements, even if nutrient reserves are sufficient to fulfill the deficiency. The rescaling of the root to shoot growth ratio is calculated as follows:

$$
\begin{aligned}
& \text { if } \frac{X_{r e q, T}-X_{u p, T}}{X_{r e q, T}} \leq 0 \text { then } q_{r-s h}=q_{r-s h, \text { norm }} \\
& \text { if } \quad 0<\frac{X_{r e q, T}-X_{u p, T}}{X_{r e q, T}}<1 \text { then } \\
& q_{r-s h}=q_{r-s h, n o r m}+\left(q_{r-s h, \text { max }}-q_{r-s h, n o r m}\right) \frac{X_{r e q, T}-X_{u p, T}}{X_{r e q, T}} \\
& \text { if } \quad \frac{X_{r e q, T}-X_{u p, T}}{X_{r e q, T}} \geq 1 \text { then } q_{r-s h}=q_{r-s h, \text { max }}
\end{aligned}
$$

As P is essential in RuBisCo regeneration (Rao \& Pessarakli 1996), $\mathrm{P}$ deficiency will limit net photosynthesis $\left(A_{n}\right)$, even though the effect of P limitation on photosynthesis is lower compared to the effect due to N shortage (Farquhar et al. 1980). We use the empirical equation derived by Reich et al. (2009) to, first, calculate the maximum net leaf photosynthesis at optimal $\mathrm{P}$ and current leaf $\mathrm{N}$ concentrations (Amax,opt), and then to calculate it at current $\mathrm{N}$ and $\mathrm{P}$ leaf concentrations $\left(A_{\max }\right)$. Lastly, the net photosynthesis calculated by ANAFORE $(A n, 0)$, which already includes any possible effects caused by $\mathrm{N}$ limitation (Deckmyn et al. 2008), is adjusted according to equation [11].

$$
A_{n}=A_{n, 0} \frac{A_{\max }}{A_{\max , o p t}}
$$

The modification of the root shoot growth ratio and the reduction in photosynthesis are implemented when $P$ concentration in leaves/needles are between deficiency and optimal concentrations. When P concentration drops below the deficiency level, and in order to reduce growth, the construction respiration costs of each pool $\left(R_{\text {con,pool }}\right)$ are increased proportionally (Deckmyn et al. 2008). Given the importance of P as structural component of nucleic acids and in cell energy transfer, we also define a critical concentration (i.e. minimum $P$ level in leaves) below which growth is stopped altogether (Mohren et al. 1986).

\subsubsection{Tree tissues aging}

On the first day of the year, before the start of the growing season, elements from current year sapwood pools are transferred to their corresponding old sapwood pools (i.e; bra0, stem 0 and $c r 0$ to bra1, stem 1 and $c r 1$, resp.), from old sapwood to heartwood pools (i.e. bra1 and stem 1 to brabark and stembark, resp.) and from current year needles (10) to old needles (l1). If a sufficient amount is present in the initial tissue pool, the corresponding older pool is supplemented up to its optimal concentration. Since the optimal concentration of older tissues is typically lower (FFCT 2013; Jacobsen et al. 2003), any remaining amount from the initial tissues is then added to the tree reserves pool (res). This is the only way in which elements may be temporarily added to the reserves pool in excess of this pool's maximum content $\left(X_{\text {res, max }}\right)$.

\subsection{Case study}

\subsubsection{Site description}

The experimental forest 'De Inslag' (51 $10^{\circ} 33^{\prime \prime} \mathrm{N}$ and $4^{\circ} 31^{\prime} 14^{\prime \prime} \mathrm{E}$ ) is located in Brasschaat in the Campine region of Belgium. 'De Inslag' is a 1.3 ha plot dominated by Scots pine (Pinus sylvestris L.) planted in 1929, that belongs to the level-II observation plot of the European Programme for the Intensive Monitoring of Forest Ecosystems. Since 1995 several researches concerning tree physiology, cycling of nutrients, $\mathrm{CO}_{2}$ and water fluxes, forest vitality and air pollution have been conducted in the plot (Overloop \& Meiresonne 1999). The location has a temperate maritime climate, with a long term mean annual temperature of $9.8^{\circ} \mathrm{C}$ and $767 \mathrm{~mm}$ of precipitation. The soil consists of a moderately wet sandy soil 
characterized by a distinct humic and/or iron B-horizon on top of an impermeable clay layer at a variable depth between 1.5 and $2 \mathrm{~m}$. The soil is classified as umbric regosol (F.A.O. classification). The organic soil layer has an average $P$ content of $446 \mathrm{mg} \mathrm{kg}^{-1}$ and the $P$ concentration in the underlying mineral layers ranges from 62 to $20 \mathrm{mg} \mathrm{kg}^{-1}$ top down (Overloop \& Meiresonne 1999).

\subsubsection{Dataset}

A dataset containing N, P and C content and dry weight of foliage, measured yearly on 1000 needles of ten trees from 1999 until 2011, ground vegetation and the different fractions of litterfall (needles, barks, branches, woody material, fruits and seeds), measured several times throughout the year from 1999 until 2013, was provided by the Instituut voor Natuur-en Bosonderzoek (INBO). Furthermore, this dataset also includes data on the thickness and composition of the organic and mineral soil layers down to a depth of $160 \mathrm{~cm}$, which were collected in 2007.

\subsubsection{Parameterization}

A Bayesian parameterization was performed for the tree species parameters, following the procedure described by Deckmyn et al. (2009). All prior distributions were initialized from the parameter values derived from previous parameterizations (Deckmyn et al. 2009) and the growth of the stand over 70 years was optimized towards measured data on tree height, biomass, diameter at breast height (DBH), gross primary productivity (GPP), net primary production (NPP), soil respiration, canopy evapotranspiration and soil $\mathrm{C}$. The model was set to run 10.000 times and the Bayesian procedure selected a posterior distribution of parameter sets. From the resulting posterior parameter distributions a random Latin hypercube sample consisting of fifteen samples was retained and used because using more parameter sets becomes too slow, but a random sample of 15 is too small: a Latin hypercube sample is partially random but takes more samples from the range with the higher likelihood so one gets a more representative sample (McKay et al. 1979). These fifteen posterior parameter sets were then used to carry out the simulations. Hence, unless stated otherwise, for each simulation all standard deviations and error bars present the variation on the runs based on these fifteen posterior parameter sets. The 15 sets of 140 parameters for Scots pine (Pinus sylvestris L.) can be obtained from the authors. A detailed analyses of the uncertainties of the ANAFORE model can be found in a publication by Horemans et al. (2016).

Parameter values with regard to optimal, maximum and deficient element concentrations were determined based on data from the Forest Foliar Coordinating Center (Vienna, Austria, operated under ICP Forests) and
Jacobsen et al. (2003). Those parameters regarding the absorption of $\mathrm{P}$ through fine roots and mycorrhizae were estimated based on results from studies on $\mathrm{P}$ absorption kinetics in Pinus sylvestris seedlings inoculated with $\mathrm{Pax}$ illus involutus (Batsch.) Fr., Suillus luteus (L.:Fr.) S. F. Gray, Suillus bovinus (L.: Fr.) O. Kuntze or Thelephora terrestris Ehrh.: Fr. (Colpaert et al. 1999; Van Tichelen \& Colpaert 2000). Parameters concerning the EM module were taken from the review by Deckmyn et al. (2014). Table A2 gives the parameter values used specific to the $\mathrm{P}$ and EM module.

\subsubsection{Simulations}

In order to demonstrate the functionality of the model concerning P limitations, three complete runs were performed after parameterization, each using 15 parameter sets. All simulations started from seedlings and ran for a period of 80 years.

In the first simulation (hereinafter "standard") we simulated the real environment.

In addition to this standard simulation, we performed a second simulation (hereinafter "unlimited P") which was identical to the standard simulation, with the sole exception that $P$ availability remained high by artificially adding $\mathrm{P}$ to the solution in each soil layer of the system at the beginning of every day. Consequently, $\mathrm{P}$ availability remained high and no limitation effects occurred. This allowed us to compare the simulated tree growth and photosynthetic capacity under contrasting situations regarding $P$ availability. Furthermore, in both simulations and starting from the fifteenth year, a harvesting system was applied in which half of the aboveground tree growth was harvested (which is similar to the actual management but simplified). Consequently, $\mathrm{P}$ was repeatedly removed from the system through harvesting. In order to illustrate how tree nutritional status and responses vary throughout the season and in addition to comparing these two simulations over the full 80 -year period, we will demonstrate the model functioning in more detail based on the 20th year of the standard model simulations. This year was arbitrarily selected since, in the standard simulation, it is located in a P-deficient period from $10-$ 40 years (see also 3.3 ).

For the third complete run, EM transfer to the trees was set to 0 as was $C$ allocation from the trees to the EM fungi, to investigate whether the model correctly simulates plant $\mathrm{P}$ uptake in the absence of EM fungi. The EM fungi in this run grew as fungi getting their energy from organic matter decay.

In addition single runs (using only the "best fit" parameter set and not the Latin hypercube sample) were run to investigate the importance of specific EM parameters: the rhizomorph fraction of EM biomass was varied $(0.1,0.3$ (standard) and 0.5$)$ and the extension $(0.05 \mathrm{~m}$, $0.1 \mathrm{~m}$ (standard), $0.2 \mathrm{~m}$ ). To compare the sensitivity of the results to fine root characteristics 2 additional runs with modified fine root turnover and modified fine root 
width were performed. Finally we changed the conventional harvest method to leave the branches on site (while in the standard run $60 \%$ are removed as is the conventional harvest in Belgium) or remove all.

\section{Results}

\subsection{Tree growth}

Since the species parameters were fitted towards stand growth, simulated tree height at the end of the 80-year period $(23.8 \mathrm{~m})$ was similar to the measured value. Tree growth is depicted in Fig. 3 for the standard and the unlimited $P$ scenario. After 80 years trees were on average $0.16 \mathrm{~m}$ smaller but total aboveground wood biomass was slightly increased under unlimited P. Still, P shortage did not occur in all of the 15 runs in the standard simulation, which may suggest that this particular forest is on the edge of becoming $\mathrm{P}$ deficient. Due to the large variation between the different runs, none of these differences were significant. Average tree $\mathrm{P}$ content at the end of the simulation period was $25.4 \mathrm{~g}$ at an average density of 1314 trees ha ${ }^{-1}$ this accounts for $33.37 \mathrm{~kg} \mathrm{ha}^{-1}$. The harvesting treatment resulted in the standard simulation in a total average over all model runs of $7927 \pm 660$ trees harvested over a period of 80 years and a total loss of 9044 $\pm 116 \mathrm{~g} \mathrm{P} \mathrm{ha}^{-1}$ from the ecosystem.

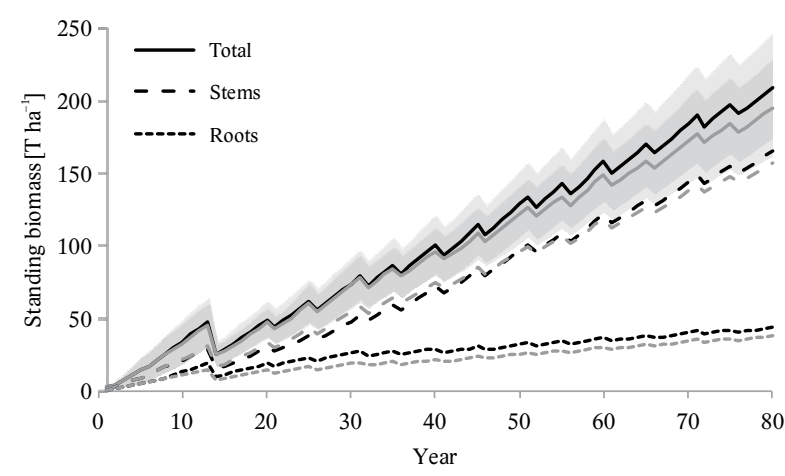

Fig. 3. Simulated total tree biomass, stem biomass and root biomass of Pinus sylvestris forest stand "De Inslag" over 80 years for the standard (grey) and unlimited P (black) runs. In order to preserve a clear overview, error bars are only shown for the total biomass. Error bars present the variation on the runs based on the fifteen posterior parameter sets of the Latin hypercube sample.

\subsection{Phosphorus in the soil}

In the $20^{\text {th }}$ year of the standard simulation, the average simulated amount of $\mathrm{P}$ fixed to organic matter in the organic soil layer is $88.01 \pm 15.83 \mathrm{~kg} \mathrm{P} \mathrm{ha}^{-1}$ whilst it was initialized at the measured value of $89.54 \mathrm{~kg} \mathrm{Pha}^{-1}$. which is similar to for example $80 \pm 3 \mathrm{~kg} \mathrm{Pha}^{-1}$ in organic soil in a forest of comparable age as reported by Yanai (1992). The $\mathrm{P}$ concentration in the soil solution is greater and more variable in the organic soil layer than in the mineral layers $\left(1.28 \pm 1.49 \mathrm{mg} \mathrm{l}^{-1}\right.$ and $0.28 \pm 0.33 \mathrm{mg} \mathrm{l}^{-1}$, respectively, standard deviations represent the variation on the yearly average), and within the $0.001-1 \mathrm{mg} \mathrm{Pl}^{-1}$ range reported for the soil solution by Brady and Weil (2008) (Fig. 4). The simulated yearly P mineralization rate of $6.54 \pm 3.80 \mathrm{~kg} \mathrm{Pha}^{-1} \mathrm{y}^{-1}$ is also comparable to the range of $5-20 \mathrm{~kg} \mathrm{P} \mathrm{ha}^{-1} \mathrm{y}^{-1}$ reported by Brady and Weil (2008). Within year variability shows that the decrease in $P$ fixed to the organic matter in the organic layer during the growing season is paralleled by an increase in the dissolved $\mathrm{P}$ concentration in the same layer. This suggests that most of the available $\mathrm{P}$ was provided through the decomposition and mineralization of litter in the organic layer (Jonard et al. 2010).

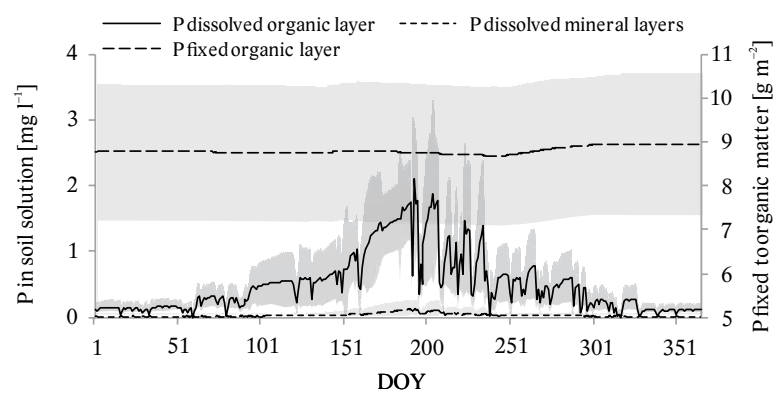

Fig. 4. Mean simulated daily amount of $P$ fixed to organic matter in the organic soil layer; and mean simulated $P$ concentration in the organic soil layer and in all soil mineral layers (mg P ${ }^{-1}$ ) during the $20^{\text {th }}$ year of the standard simulation. Error bars present the variation on the runs based on the fifteen posterior parameter sets of the Latin hypercube sample.

\subsection{Phosphorus uptake}

$\mathrm{P}$ uptake rates are in line with expected values based on experimental data. The mean simulated yearly total P uptake by adult trees $(40-80$ years $)$ is $2.01 \pm 0.47 \mathrm{~g}$ $\mathrm{P} \mathrm{m}^{-2} \mathrm{y}^{-1}$, which is quite high compared to the value of $0.96 \mathrm{~g} \mathrm{P} \mathrm{m}^{-2} \mathrm{y}^{-1}$ reported by Yanai (1992) in forests of similar age and with comparable aboveground biomass. The $\mathrm{P}$ uptake rate through diffusion by mycorrhizae is highly correlated $\left(\mathrm{R}_{2}=0.79\right)$ to seasonal changes in the simulated total amount of $P$ released from litter through decomposition. In contrast, the total P uptake rate in trees show no correlation $\left(\mathrm{R}_{2}=0.101\right)$ with the daily amount of P released from litter through decomposition. This can be explained by the fact that on average $94.29 \pm 24.13 \%$ of the $\mathrm{P}$ released through decomposition in every time step is taken up through diffusion by the mycorrhizae and allocated to their reserve pool. Indeed, $97.87 \pm 41.93 \%$ of the total P supplied to the tree (Fig. 5) is transferred from mycorrhizae to the host plants, which is consistent with global estimations that range around 90\% (Deckmyn et al. 2014). In spite of P uptake through diffusion and uptake through fine roots along with water showing a similar seasonality to P uptake by mycorrhizae, their con- 
tribution to the $\mathrm{P}$ supply to trees is on average relatively small $(2.03 \pm 1.27 \%$ and $0.09 \pm 0.03 \%$, respectively, Fig. 5). These results demonstrate the importance of incorporating mycorrhizae in simulating P supply to trees. Mycorrhizae not only contribute most to P supply to trees but also supply P to the trees relatively independent of the mineralization rate, helping to overcome the sudden rise in P requirement at the beginning of the growing season.

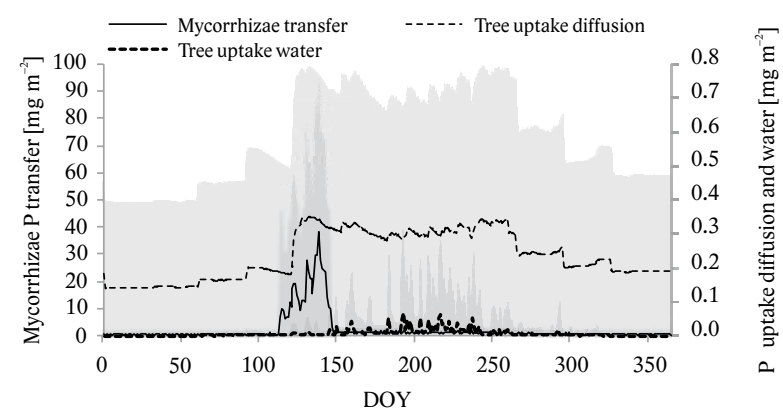

Fig. 5. Mean simulated relative contributions of $P$ uptake through fine root diffusion and $\mathrm{P}$ transferred from mycorrhizae in the 20th year of the standard model run. Error bars present the variation on the runs based on the fifteen posterior parameter sets of the Latin hypercube sample.

\subsection{Phosphorus in tree tissues}

Seasonal variation in the allocation of $\mathrm{P}$ to both the physical tissue pools and the non-physical temporary reserve pool consists of a sudden drop in the $\mathrm{P}$ content of the tree's reserve pool and, when the translocated amount of $P$ is insufficient to meet the requirements associated with the tree growth at the beginning of the growing season, of the internal reserves tissue pools (Fig. 6), thus corresponding to the expected pattern described by Chapin et al. (1990). P requirement is driven by tree growth, increasing at the start of the growing season due to the formation of new needles, sapwood and roots. The high amount of $\mathrm{P}$ needed to meet growth requirements at the start of the growing season is mainly supplied by the reserve pool of the tree. However, the within-year variability of P requirements and the level of the reserve pool are driven by the nutritional status of the tree demonstrating the ability of the model to react to contrasting nutrient availabilities. In the unlimited $\mathrm{P}$ simulation, the reserve pool supplies the required $\mathrm{P}$, whereas in some runs of the standard simulation the reserves are completely depleted leading to an increase in requirements because tissues grew at suboptimal P concentrations. After the spring growth flush requirements decrease to basal values in the case of the unlimited P simulation. In the standard simulation, requirements remain high because of $\mathrm{P}$ deficiency in tree tissues, yet gradually decrease due to P supply by uptake. In autumn requirements decreased at a higher rate due to retranslocation when litterfall occurs and, when these requirements are met, the reserve pool
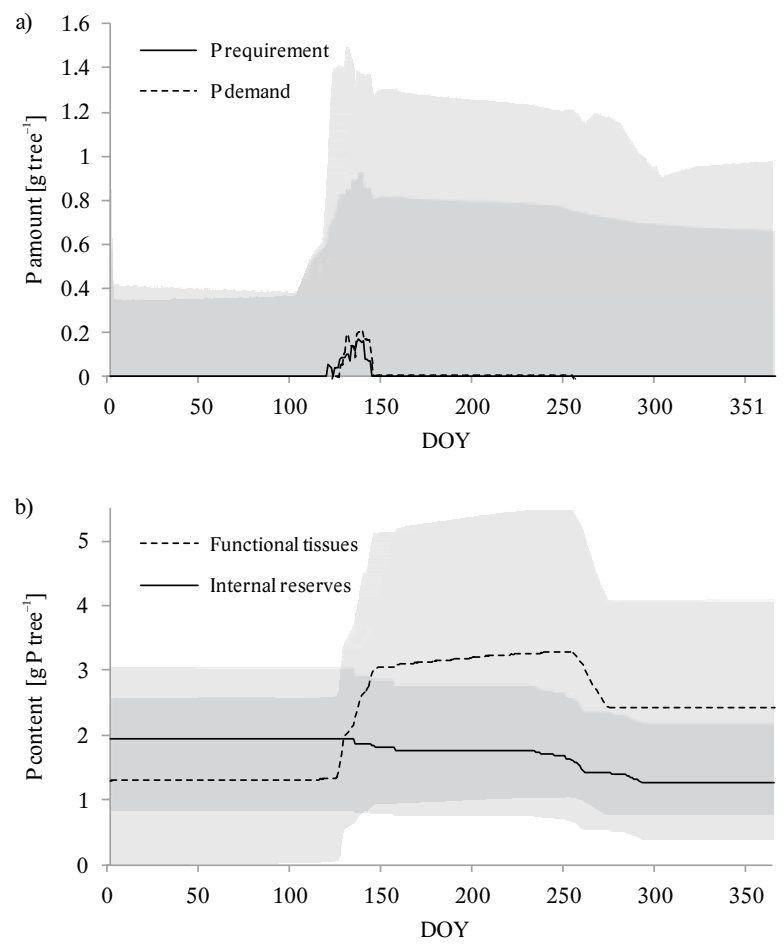

Fig. 6. (a) Mean simulated daily requirement and amount of $P$ stored in the tree reserve pool, and (b) mean standard deviations from the Latin hypercube sample of model parameters; (b) Mean simulated total P content of all functional and internal reserves tissue pools in the 20th year of the standard simulation and standard deviations from the Latin hypercube sample of model parameters.

is replenished also slowly through $\mathrm{P}$ uptake and more rapidly through retranslocation from litterfall.

In order to illustrate how trees react to $\mathrm{P}$ shortage according to their nutritional status throughout the season, we arbitrarily selected the $20^{\text {th }}$ year to demonstrate the functioning of the model (Fig. 1). This year is located in the P-deficient period of tree growth from $10-40$ years (Fig. 7).

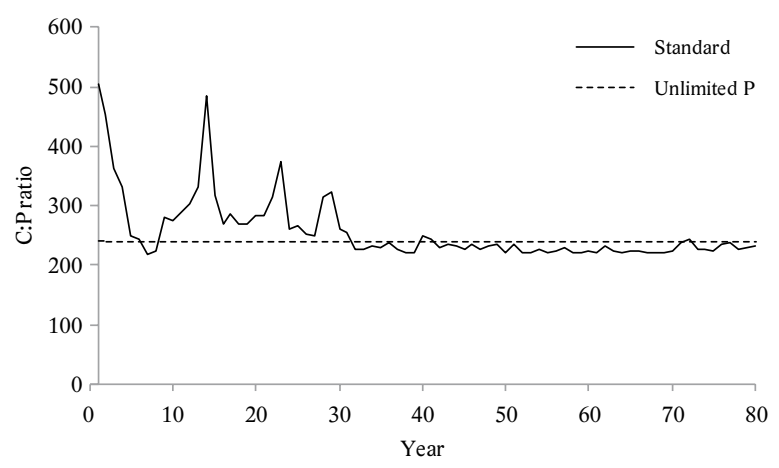

Fig. 7. Yearly average C:P ratio in current year needles for the standard simulation (full line) and under unlimited $\mathrm{P}$ (dashed line). In order to preserve a clear overview, no error bars are shown. 


\subsection{Phosphorus shortage effects}

Trees respond to nutrient deficiency by increasing $\mathrm{C}$ allocation to roots in order to capture more nutrients (Marschner et al. 1996). In our model, root to shoot growth ratio is modified at the moment when nutrient uptake is not sufficient to meet the growth requirements, thus this effect occurs at an earlier stage than the reduction of the photosynthetic capacity, which becomes active once the $\mathrm{P}$ concentration is below optimum. This is true both at a small temporal scale as well as on a scale of several years when comparing yearly averages. Accordingly, under limited conditions root to shoot growth ratio suddenly increases at the beginning of the growing season as a consequence of the high P requirements. In parallel to requirements, the root to shoot growth ratio decreases in autumn when retranslocation from litterfall occurs and requirements decrease. In contrast to limited conditions, the root to shoot growth ratio under non-limited conditions remains at the initial ANAFORE value of 0.25 throughout the year after the first initial years (saplings have a higher ratio). Over the 80 year period the shortage between $10-40$ years leads to an increased ratio but the difference decreases after $40^{\text {th }}$ year when P-limitation has disappeared (Fig. 8).

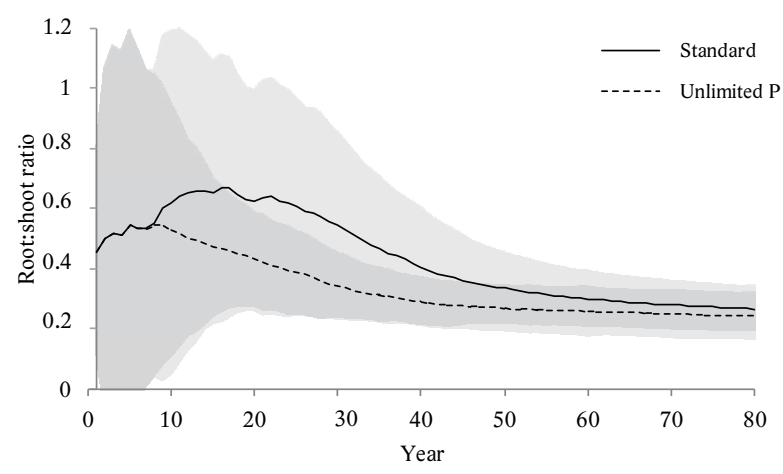

Fig. 8. Root:shoot ratio during stand growth for the standard simulation (full line) and under unlimited P (dashed line). Error bars present the variation on the runs based on the fifteen posterior parameter sets of the Latin hypercube sample.

With regards to the effect of P deficiency on photosynthesis, the maximum reduction compared to the unlimited P simulation occurs at the beginning of the growing season, when P shortage is higher (Fig. 9). Then, this effect gradually decreases with decreasing $P$ requirements and thus shortage. Still, under non-limited conditions, there is a reduction of $9.09 \pm 0.08 \%$ in photosynthetic capacity from the beginning of the year up to the moment when new needles grow (beginning of growing season), followed by a stable period during which the photosynthetic capacity is reduced by $0.25 \pm 0.43 \%$, even though $P$ supply was sufficient to meet $P$ requirements. This is because until bud break, only old needles were present, which have a lower optimum P concentration, and consequently a slightly lower photosynthetic capacity. This result shows that the model is not only improved through the addition of feedback effects in case of P deficiency, but also through reduction of the photosynthetic capacity due to the aging of needles.

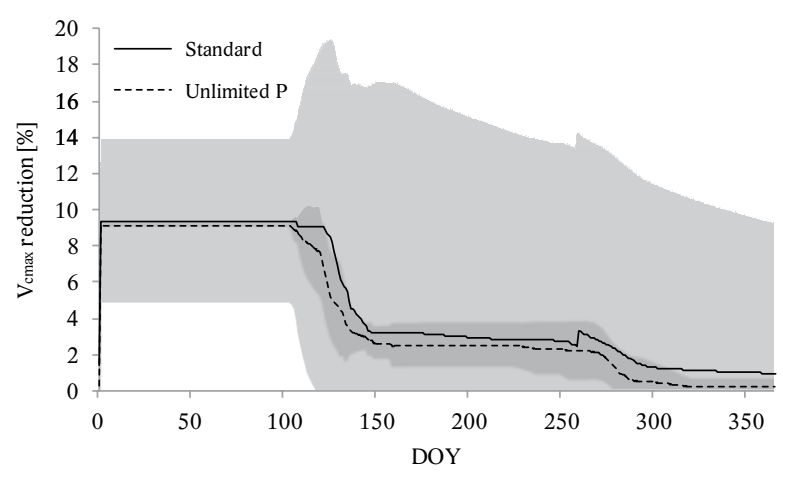

Fig. 9. Simulated daily reduction of the Vcmax photosynthesis parameter in the 20th year of the standard and unlimited $\mathrm{P}$ simulations and standard deviations from the Latin hypercube sample of model parameters.

\subsection{Influence of EM}

Running the model without EM interaction resulted in a significant but gradual decrease in stand growth both in terms of biomass and in terms of tree height (Table 1). In addition, soil $C$ and $P$ were severely reduced.

This confirms what has been suggested concerning the important role of EM not only towards plant nutrition but also towards stabilizing soil nutrient and $\mathrm{C}$ content. This result is of course also influenced by the parameters used. However, one less realistic outcome is that EM biomass remains quite high. $10 \%$ of plant $C$ allocated to the roots is 'traded' with the EM in the standard run, whereas in the non-mycorrhizal run the trees do not, indicating the EM fungi as simulated in the model are able to get enough energy and $\mathrm{C}$ by litter decay instead of the $\mathrm{C}$ they normally receive from the trees.

The uptake characteristics of the EM hyphae were set equal to those of the fine roots since we had no sitespecific data although one would expect them to be different in reality (see Introduction). Setting them equal is a conservative option reducing the importance of the EM. The difference in uptake efficiency is therefore simply due to the higher surface area of the hyphae.

\subsection{Influence of EM parameters}

Increasing or decreasing rhizomorph fraction by a factor 2 hardly changes the model outcome at an ecosystem scale (Table 1), although the turnover rate of the rhizomorphs was set at 450 days compared to 20 for the hyphae which is an extreme difference. Of course, total EM biomass is quite low (up to $500 \mathrm{~g} \mathrm{~m}^{-2}$ have been found (Wallander et al. 2004), but data are highly variable (Deckmyn et al. 
2014)). Furthermore we did not include any other effect of the rhizomorphs except a longer lifetime. Increasing the extension of the EM fungi also had no effect on the ecosystem at a 80 year time frame.

\subsection{Influence of FR parameters}

Fine roots are an important $C$ sink in the forest ecosystem. Uncertainty concerning the turnover rate of fine roots is known to influence the model results and stand data generally include all roots below $2 \mathrm{~mm}$ in the fine root pool while some of these are known to be different concerning function (transport or uptake) and longevity (slower turnover). If we assume fine roots are $1 \mathrm{~mm}$, more root area can be produced per unit invested C. However, because the uptake is dominated by the EM this has little influence on the ecosystem functioning. Increasing yearly FR turnover from $41 \%$ to $49 \%$ had a relatively important impact on the $\mathrm{C}$ flows and stocks in the ecosystem: stem biomass was reduced by $10 \%$ while soil $\mathrm{C}$ and P stocks were slightly increased (Table 1). This is important to note because the uncertainty on fine root turnover is high.

\subsection{Influence of management}

The harvesting treatment resulted in the standard simulation in a total average over all model runs a total loss of $9044 \pm 116 \mathrm{~g} \mathrm{P} \mathrm{ha}^{-1}$ from the ecosystem. Leaving the branches on site at harvest resulted in an $1.5 \%$ increase in soil $P$, which could become important since soil $P$ is close to being limiting at the particular studied site.

The largest loss is at the final harvest, which was not included in this run (this would have an effect during a second rotation) so long-term effects would be more significant.

\section{Discussion}

To the best of our knowledge, this is the first mechanistic model that simulates the detailed cycling of $P$ in the whole temperate forest ecosystem, including uptake and transfer of $\mathrm{P}$ by EM, Pallocation within the trees and feedback effects of $\mathrm{P}$ limitation on growth, $\mathrm{C}$ allocation and photosynthetic capacity. Our results confirm the importance of incorporating mycorrhizae in forest ecosystem models since they do not only increase the $P$ availability to the trees but also buffer its availability by providing a $\mathrm{P}$ source relatively more independent from mineralization rates. Furthermore, the model simulates increasing tree $\mathrm{P}$ requirements at the beginning of the growing season and, when these requirements are not met, decreased growth and photosynthetic capacity. Therefore, our results support the need for including the cycling of $P$ and the effect of $\mathrm{P}$ deficiency in forest ecosystem models (Braun et al. 2010). In view of these results and the increasing body of evidences that suggest a shift in nutrient limitation in terrestrial ecosystems from $\mathrm{N}$ to $\mathrm{P}$ (Marschner et al. 1996; de Vries et al. 2009; Peñuelas et al. 2012, 2013), the lack of consideration of $P$ and its effect on trees in many modeling studies might lead to an overestimation of forest growth and productivity in local and global models, and therefore to an overestimation of the mitigating potential of forests under limited nutrient conditions (FernándezMartínez et al. 2014; Jonard et al. 2015).

Nevertheless, from the large variance on simulated output variables can be inferred that for many parameters a large uncertainty exists. It is important that the expected increase in forest models that simulate the cycling of $\mathrm{P}$, is accompanied by an increase in data collected from field measurements and experimental setups, particularly regarding $\mathrm{P}$ absorption by fine roots and mycorrhizae and transfer from mycorrhizae to trees, since these mechanisms are key in every P model but are at the same time scarce and therefore difficult to evaluate. The strong response of tree growth in the non-mycorrhizal run is impossible to evaluate since EM are common in temperate forest, and the simulated trees grow fine the firstyears which is the only thing one could study in an experiment.

Our results suggest that although the fractioning between EM hyphae and rhizomorphs has a large effect on the turnover of the EM, the effect on the ecosystem is marginal. Likewise the extension of the EM in a mature forest did not substantially influence soil processes. It appears that model simplification is possible for many applications unless EM are specifically investigated. However, the sensitivity of the model results to fine root turnover is cause for concern, since measured data do not only show large variation between sites and species but also between observation methods, further stressing the importance of improving empirical estimations of fine root turnover rates (McCormack et al. 2015).

Since EM infect all pine trees, one could, if the mere simulation of tree growth were the main aim of the implementation, include their characteristics such as the increased extension and surface area implicitly in the parameters of the tree fine roots by simulating thinner roots that extend further. Moreover, given the high number of parameters and the complexity of mechanistic forest models, one could parameterize a model to fit the current growth of a forest without $\mathrm{P}$ and/or EM. However this would not be sufficient to capture the stabilizing effect of EM on soil nutrient availability nor the capacity of EM to degrade organic compounds. The added value of the full mechanistic model is in a better understanding of the mechanisms of nutrient uptake and feedbacks, and of the true limitations to tree growth from soil nutrient limitation. In addition the possibility to understand and predict qualitatively (if not quantitatively) the effects of changes in soil biodiversity and forest management on forest nutritional status and functioning is the main goal of this model elaboration. 
The successful simulation of a simple management scenario, such as harvesting, indicates that this model is a suitable tool to study the impact of different management scenarios on forest productivity within a global change context, though additional validation of this aspect is necessary. The fact that in the standard simulation not all of the runs using the different Latin hypercube parameters samples resulted in $\mathrm{P}$ limitation may indicate that the described forest, 'De Inslag', is on the edge of becoming $\mathrm{P}$ deficient. This corresponds to field measurements in this particular forest suggesting that $\mathrm{P}$ deficiency symptoms in the trees are latent but are expected to be amplified through time under the effect of increasing $\mathrm{N}$ deposition (Roskams \& Neirynck 1999). Since the harvesting of trees results in a removal of $P$ from the system, our results substantiate the concern that tree harvesting may induce or amplify this P deficit and corroborate earlier findings that small changes in conventional harvest methods such as leaving branches on site can mitigate $P$ loss (Mälkönen 1976; Grigal 2000).

The general description of element cycling in the model provides an excellent basis to simulate different elements, other than $\mathrm{N}$ and $\mathrm{P}$, in forest ecosystem models. Indeed, nutrients such as $\mathrm{K}, \mathrm{Mg}$, or $\mathrm{Ca}$, which may become limiting in European forest ecosystems in the future (Jonard et al. 2012, 2015) or toxic elements such as $\mathrm{Cd}$ or $\mathrm{Pb}$ (among others) could be easily simulated by adapting the uptake parameters and the effect of limitation or toxicity on tree growth. However, while optimal, deficiency and maximum concentrations in plant tissues are generally well known (e.g. Jacobsen et al. 2003), only very few parameter values concerning the uptake and transfer Michaelis-Menten equations and the effects on growth and photosynthesis are specified in literature (e.g. Jongbloed 1991). Further experimental studies are therefore necessary to define these model parameters in order to incorporate these elements in forest ecosystem models.

\section{Acknowledgments}

This work was supported by the BELSPO (Belgian Science Policy) project ECORISK (contract SD/R1/06A) and co-funding by the Slovenian Research Agency through the research programme Forest biology, ecology and technology (P4-0107) is acknowledged. E. Andivia was beneficiary of a FSR Incoming Post-doctoral Fellowship of the Académie Universitaire "Louvain", cofunded by the Marie Curie Actions of the European Commission, and of a postdoctoral grant "Ayudas para contratos para la formación postdoctoral" (FPDI-2013-15573) funded by the Ministry of Economy of the Spanish Government. Finally we acknowledge COST action FP1305 Biolink.

\section{References}

Barber, S.A., 1995: Soil nutrient bioavailability: a mechanistic approach $2^{\text {nd }}$ edition. New York, John Wiley \& Sons, 418 p.
Boisvenue, C., Running, S. W., 2006: Impacts of climate change on natural forest productivity-evidence since the middle of the $20^{\text {th }}$ century. Global Change Biology, 12:862-882.

Bontemps, J. D., Hervé, J. C., Leban, J. M., Dhôte, J. F., 2011: Nitrogen footprint in a long-term observation of forest growth over the twentieth century. Trees, 25:237-251.

Brady, N.C., Weil, R. R., 2008: The nature and properties of soils. $14^{\text {th }}$ ed. Upper Saddle River, Pearson Prentice Hall, 975 p.

Braun, S., Thomas, V. F., Quiring, R., Flückiger, W., 2010: Does nitrogen deposition increase forest production? The role of phosphorus. Environmental Pollution, 158:2043-2052.

Chapin III, F. S., Schulze, E. D., Mooney, H.A., 1990:The ecology and economics of storage in plants. Annual Review of Ecology and Systematics, 21:423-447.

Colpaert, J. V., Van Tichelen, K. K., Van Assche, J. A., Van Laere, A., 1999: Short-term phosphorus uptake rates in mycorrhizal and non-mycorrhizal roots of intact Pinus sylvestris seedlings. New Phytologist, 143:589-597.

de Vries, W., Solberg, S., Dobbertin, M., Sterba, H., Laubhann, D., Van Oijen, M. et al., 2009: The impact of nitrogen deposition on carbon sequestration by European forests and heathlands. Forest Ecology and Management, 258:1814-1823.

Deckmyn, G., Verbeeck, H., De Beeck, M. O., Vansteenkiste, D., Steppe, K., Ceulemans, R., 2008:ANAFORE: a stand-scale process-based forest model that includes wood tissue development and labile carbon storage in trees. Ecological Modelling, 215:345-368.

Deckmyn, G., Mali, B., Kraigher, H., Torelli, N., Ceulemans, R., 2009: Using the process-based stand model ANAFORE including Bayesian optimisation to predict wood quality and quantity and their uncertainty in Slovenian beech. Silva Fennica, 43:523-534.

Deckmyn, G., Campioli, M., Muys, B., Kraigher, H., 2011: Simulating C cycles in forest soils: Including the active role of micro-organisms in the ANAFORE forest model. Ecological Modelling, 222:1972-1985.

Deckmyn, G., Meyer, A., Smits, M. M., Ekblad, A., Grebenc, T., Komarov, A. et al., 2014: Simulating ectomycorrhizal fungi and their role in carbon and nitrogen cycling in forest ecosystems. Canadian Journal of Forest Research, 44:535-553.

Dzotsi, K. A., Jones, J. W., Adiku, S. G. K., Naab, J. B., Singh, U., Porter, C. H. et al., 2010: Modeling soil and plant phosphorus within DSSAT. Ecological Modelling, 221:2839-2849.

Farquhar, G.V., von Caemmerer, S. V., Berry, J.A., 1980: Abiochemical model of photosynthetic $\mathrm{CO}_{2}$ assimilation in leaves of C3 species. Planta, 149:78-90.

Fernández-Martínez, M., Vicca, S., Janssens, I. A., Campioli, M., 2014: Nutrient availability as the key regulator of global forest carbon balance. Nature Climate Change, 4:471-476. 
FFCT, 2013: Minutes of the 13th ICP Forest EP Foliage and Litterfall meeting. International Co-operative Programme on Assessment and Monitoring of Air Pollution Effects on Forests of UN/ECE (ICP Forests), Ljubljana, Slovenia.

Franklin, O., Naesholm, Hoegberg, P., Hoegberg, M. N., 2014: Forests trapped in nitrogen limitation - an ecological market perspective on ectomycorrhizal symbiosis. New Phytologist, 203:657-666.

Gérard, F., Blitz-Frayret, C., Hinsinger, P., Pagès, L. 2017: Modelling the interactions between root system architecture, root functions and reactive transport processes in soil. Plant and Soil, 413:161-180.

Grigal, D. F., 2000: Effects of extensive forest management on soil productivity. Forest Ecology and Management, 138:167-185.

Hinsinger, P., Brauman, A., Devau, N., Gérard, F., Jourdan, C., Laclau, J. P. et al., 2011: Acquisition of phosphorus and other poorly mobile nutrients by roots. Where do plant nutrition models fail? Plant and Soil, 348:29-61.

Horemans, J.A., Bosela, M., Dobor, L., Barna, M., Bahyl, J., Deckmyn, G. et al., 2016: Variance decomposition of stem biomass increment predictions for European beech: contribution of selected sources of uncertainty. Forest Ecology and Management, 361:46-55.

Jacobsen, C., Rademacher, P. Meesenburg, H., Meiwes, K. J., 2003: Gehalte chemischer Elemente in den Baumkompartimenten: Literaturstudie und Datensammlung. Göttingen, Selbstverlag des Forschungszentrums Waldökosysteme der Universität Göttingen, 88 p.

Jeppu, G. P., Clement, T. P., 2012: A modified Langmuir-Freundlich isotherm model for simulating $\mathrm{pH}$ dependent adsorption effects. Journal of Contaminant Hydrology, 129:46-53.

Jonard, M., Augusto, L., Hanert, E., Achat, D. L., Bakker, M. R., Morel, C. et al., 2010: Modeling forest floor contribution to phosphorus supply to maritime pine seedlings in two-layered forest soils. Ecological Modelling, 221:927-935.

Jonard, M., Legout, A., Nicolas, M., Dambrine, E., Nys, C., Ulrich, E. et al., 2012: Deterioration of Norway spruce vitality despite a sharp decline in acid deposition: a long-term integrated perspective. Global Change Biology, 18:711-725.

Jonard, M., Fürst, A., Verstraeten, A., Thimonier, A., Timmermann, V., Potočić, N. et al., 2015: Tree mineral nutrition is deteriorating in Europe. Global Change Biology, 21:418-430.

Jones, C. A., Cole, C. V., Sharpley, A. N., Williams, J. R., 1984: A simplified soil and plant phosphorus model: I. Documentation. Soil Science Society of America Journal, 48:800-805.
Jongbloed, R. H., Clement, J. M. A. M., Borst-Pauwels, G. W. F. H., 1992: Effects of aluminium and $\mathrm{pH}$ on growth and potassium uptake by three ectomycorrhizal fungi in liquid culture. Plant and Soil, 140:157165.

Landsberg, J. J., Kaufmann, M. R., Binkley, D., Isebrands, J., Jarvis, P. G., 1991: Evaluating progress toward closed forest models based on fluxes of carbon, water and nutrients. Tree Physiology, 9:1-15.

Lindahl, B. D., Tunlid, A., 2014: Ectomycorrhizal fungipotential organic matter decomposers, yet not saprotrophs. New Phytologist, 205:1443-1447.

Marschner, H., Kirkby, E. A., Cakmak, I., 1996: Effect of mineral nutritional status on shoot-root partitioning of photoassimilates and cycling of mineral nutrients. Journal of Experimental Botany, 47:1255-1263.

McKay, M. D., Beckman, R. J., Conover, W. J., 1979: Comparison of three methods for selecting values of input variables in the analysis of output from a computer code. Technometrics, 21:239-245.

McCormack, M. L., Crisfield, E., Raczka, B., Schnekenburger, F., Eissenstat, D. M., Smithwick, E. A., 2015: Sensitivity of four ecological models to adjustments in fine root turnover rate. Ecological modelling, 297: 107-117.

Meerts, P., 2002: Mineral nutrient concentrations in sapwood and heartwood: a literature review. Annals of Forest Science, 59:713-722.

Meyer, A., Grote, R., Butterbach-Bahl, K., 2012: Integrating mycorrhiza in a complex model system - effects on ecosystem $\mathrm{C}$ and $\mathrm{N}$ fluxes. European Journal of Forest Research, 131:1809-1831.

Mohren, G. M. J., Van Den Burg, J., Burger, F. W., 1986: Phosphorus deficiency induced by nitrogen input in Douglas fir in the Netherlands. Plant and Soil, 95:191-200.

Mälkönen, E., 1976: Effect of whole-tree harvesting on soil fertility. Silva Fennica, 3:157-164.

Norby, R. J., Warren, J. M., Iversen, C. M., Medlyn, B. E., McMurtrie, R. E., 2010: $\mathrm{CO}_{2}$ enhancement of forest productivity constrained by limited nitrogen availability. Proceedings of the National Academy of Sciences, 107:19368-19373.

Nowak, R. S., Ellsworth, D. S., Smith, S. D., 2004: Functional responses of plants to elevated atmospheric $\mathrm{CO}_{2}$-do photosynthetic and productivity data from FACE experiments support early predictions? New Phytologist, 162:253-280.

Orwin, K. H., Kirschbaum, M. U. F., St John, M. G., Dickie, I. A., 2011: Organic nutrient uptake by mycorrhizal fungi enhances ecosystem carbon storage: a model-based assessment. Ecology Letters, 14:493502 . 
Overloop, S., Meiresonne, L., 1999: Basiskarakteristieken van het proefvlak Brasschaat, domeinbos de Inslag. Mededelingen van het Instituut voor Bosbouw en Wildbeheer, 1:11-21.

Parton, W. J., Stewart, J.W., Cole, C. V., 1988: Dynamics of $\mathrm{C}, \mathrm{N}, \mathrm{P}$ and $\mathrm{S}$ in grassland soils: a model. Biogeochemistry, 5:109-131.

Peñuelas, J., Sardans, J., Rivas-ubach, A., Janssens, I. A., 2012: The human-induced imbalance between C, N and $\mathrm{P}$ in Earth's life system. Global Change Biology, 18:3-6.

Peñuelas, J., Poulter, B., Sardans, J., Ciais, P., Van Der Velde, M., Bopp, L. et al., 2013: Human-induced nitrogen-phosphorus imbalances alter natural and managed ecosystems across the globe. Nature Communications, 4:2934.

Probert, M.E., Keating, B.A., 2000: What soil constraints should be included in crop and forest models? Agriculture, Ecosystems and Environment, 82:273-281.

Rao, I. M., Pessarakli, M., 1996: The role of phosphorus in photosynthesis. In: Pessarakli, M. (ed.): Handbook of Photosynthesis, Marcel Dekker, Inc., New York, p. 173-194.

Read, D., Perez-Moreno, J., 2003: Mycorrhizas and nutrient cycling in ecosystems - a journey towards relevance? New Phytologist, 157:475-492.

Read, D. J., Leake, J. R., Perez-Moreno J., 2004: Mycorrhizal fungi as drivers of ecosystem processes in heathland and boreal forest biomes. Canadian Journal of Botany, 82:1243-1263.

Reich, P. B., Oleksyn, J., Wright, I. J., 2009: Leaf phosphorus influences the photosynthesis-nitrogen relation: a cross-biome analysis of 314 species. Oecologia, 160:207-212.

Roskams, P., Neirynck, J., 1999: De voedingstoestand van Grove den (Pinus sylvestris L.) in het level II-proefvlak in Brasschaat. Mededelingen van het Instituut voor Bosbouw en Wildbeheer, 1:23-42.

Runyan, C.W., P.D‘Odorico, 2012: Hydrologic controls on phosphorus dynamics: A modeling framework. Advances in Water Resources 35:94-109.
Schnepf, A., Roose, T., 2006: Modelling the contribution of arbuscular mycorrhizal fungi to plant phosphate uptake. New Phytologist, 171:669-682.

Shah, F., Nicolás, C., Bentzer, J., Ellström, M., Smits, M., Rineau, F. et al., 2016: Ectomycorrhizal fungi decompose soil organic matter using oxidative mechanisms adapted from saprotrophic ancestors. New Phytologist, 209:1705-1719.

Toman, M.A., Ashton, P. M. S., 1996: Sustainable forest ecosystems and management: a review article. Forest Science, 42:366-377.

Van Tichelen, K. K., Colpaert, J. V., 2000: Kinetics of phosphate absorption by mycorrhizal and non-mycorrhizal Scots pine seedlings. Physiologia Plantarum, 110:96-103.

Vereecken, H., Schnepf, A., Hopmans, J. W. et al., 2016: Modeling soil processes: review, key challenges and new perspectives. Vadose Zone Journal, 15:1-57.

Vitousek, P. M., Porder, S., Houlton, B.Z., Chadwick, O. A., 2010: Terrestrial phosphorus limitation: mechanisms, implications, and nitrogen-phosphorus interactions. Ecological Applications, 20:5-15.

Wallander, H., Göransson, H., Rosengren, U., 2004: Production, standing biomass and natural abundance of ${ }^{15} \mathrm{~N}$ and ${ }^{13} \mathrm{C}$ in ectomycorrhizal mycelia collected at different soil depths in two forest types. Oecologia, 139:89-97.

Yanai, R. D., 1992: Phosphorus budget of a 70-yearold northern hardwood forest. Biogeochemistry, 17:1-22.

Zhenh, W., Morris, E. K., Rillig, M. C., 2014: Ectomycorrhizal fungi in association with Pinus sylvestris seedlings promote soil aggregation and soil water repellency. Soil Biology en Biochemistry, 78:326-331.

Zinke, P. J., 1962: The pattern of influence of individual forest trees on soil properties. Ecology, 43:130-133. 


\section{Appendix tables}

Table A1. List of symbols.

\begin{tabular}{|c|c|c|}
\hline Symbol & Unit & Definition \\
\hline$[\mathrm{X}]_{\text {def }, \text { pool }}$ & $\mathrm{kg} \mathrm{X} \mathrm{kg}^{-1} \mathrm{C}$ & Tissue pool deficiency concentration \\
\hline$[\mathrm{X}]_{\text {lim,trans }}$ & $\mathrm{kg} \mathrm{X} \mathrm{kg}^{-1} \mathrm{C}$ & Threshold concentration in mycorrhizal reserves pool for transfer to trees \\
\hline$[\mathrm{X}]_{\text {myc, res }}$ & $\mathrm{kgX} \mathrm{kg} \mathrm{C}^{-1}$ & Concentration in mycorrhizal reserves pool \\
\hline$[\mathrm{X}]_{\text {opt,pool }}$ & $\mathrm{kgX} \mathrm{kg} \mathrm{C}^{-1}$ & Optimal Concentration in tree tissue pool \\
\hline$[\mathrm{X}]_{\text {pool }}$ & $\operatorname{kgXkgC}{ }^{-1}$ & Concentration in tree tissue pool \\
\hline$[\mathrm{X}]_{\text {max,pool }}$ & $\mathrm{kg} \mathrm{X} \mathrm{kg} \mathrm{C}^{-1}$ & Toxic Concentration in tree tissue pool \\
\hline $\mathrm{A}_{\max }$ & $\mu \mathrm{mol} \mathrm{m} \mathrm{m}^{-2} \mathrm{~s}^{-1}$ & Net photosynthesis at current leaf $\mathrm{N}$ and $\mathrm{P}$ concentrations \\
\hline $\mathrm{A}_{\max , o p t}$ & $\mu \mathrm{mol} \mathrm{m} \mathrm{s}^{-2} \mathrm{~s}^{-1}$ & Net photosynthesis at current leaf $\mathrm{N}$ and optimal $\mathrm{P}$ concentrations \\
\hline $\mathrm{A}_{n}$ & $\mu \mathrm{mol} \mathrm{m}{ }^{-2} \mathrm{~s}^{-1}$ & P adjusted net photosynthesis \\
\hline$A_{n, 0}$ & $\mu \mathrm{mol} \mathrm{m}{ }^{-2} \mathrm{~s}^{-1}$ & Net photosynthesis as calculated by main ANAFORE \\
\hline $\mathrm{c}_{\text {lim,pool }}$ & $\mathrm{kg} \mathrm{X} \mathrm{m}^{-3}$ & Limiting soil solution concentration for uptake \\
\hline $\mathrm{c}_{p(i)}$ & $\mathrm{kgX} \mathrm{m}^{-3}$ & Dissolved concentration in soil layer $i$ \\
\hline $\mathrm{C}_{\text {pool }}$ & $\mathrm{kgC}$ & Carbon content of tree tissue pool \\
\hline $\mathrm{C}_{\text {pool(i) }}$ & $\mathrm{kgC}$ & Fine root or mycorrhizal $C$ content in soil layer $i$ \\
\hline $\mathrm{f}_{X, \text { temp }}$ & dimensionless & Fraction mobilized from old tissues \\
\hline $\mathrm{f}_{z, \mathrm{fr}(i)}$ & dimensionless & Fine root rooting zone effect for soil layer $i$ \\
\hline $\mathrm{f}_{z, m y c(i)}$ & dimensionless & Rooting zone effect including hyphae for soil layer $i$ \\
\hline$I_{\text {max,pool }}$ & $\mathrm{kg} \mathrm{X} \mathrm{m}^{-2}$ & Maximum absorption rate per absorption surface \\
\hline $\mathrm{I}_{\text {max,trans }}$ & $\operatorname{kg} X$ & Maximum transfer rate from mycorrhizae to trees \\
\hline $\mathrm{K}_{\text {m,pool }}$ & $\mathrm{kgX} \mathrm{m}^{-3}$ & Michaelis constant for uptake through diffusion \\
\hline $\mathrm{K}_{m, \text { trans }}$ & $\mathrm{kgX} \mathrm{kg}^{-1} \mathrm{C}$ & Michaelis constant for transfer from mycorrhizae to trees \\
\hline $\mathrm{K}_{p 1}$ & time $^{-1}$ & Flux parameter from the primary to the labile soil mineral $\mathrm{P}$ pool \\
\hline $\mathrm{K}_{p 2}$ & time $^{-1}$ & Flux parameter from the labile to the active soil mineral $\mathrm{P}$ pool \\
\hline $\mathrm{K}_{p 3}$ & time $^{-1}$ & Flux parameter from the active to the labile soil mineral $P$ pool \\
\hline $\mathrm{K}_{p 4}$ & time $^{-1}$ & Flux parameter from the active to the stable soil mineral $P$ pool \\
\hline $\mathrm{K}_{p 5}$ & time $^{-1}$ & Flux parameter from the stable to the active soil mineral $P$ pool \\
\hline $\mathrm{K}_{\text {plang }}$ & $\mathrm{kg} \mathrm{P} \mathrm{m}^{-3}$ solution & Inverse of the Langmuir affinity constant (P sorption isotherm) \\
\hline $\mathrm{P}_{\text {act }}$ & $\mathrm{kg} \mathrm{P} \mathrm{kg}^{-1}$ soil & Active $P$ pool in the mineral soil layers \\
\hline $\mathrm{P}_{a d s}$ & $\mathrm{~kg} \mathrm{P} \mathrm{kg}^{-1}$ soil & Adsorbed $\mathrm{P}$ pool in the mineral soil layers \\
\hline $\mathrm{P}_{l a b}$ & $\mathrm{~kg} \mathrm{P} \mathrm{kg}^{-1}$ soil & Labile P pool in the mineral soil layers \\
\hline $\mathrm{P}_{\max }$ & $\mathrm{kg} \mathrm{P} \mathrm{kg}^{-1}$ soil & Maximum soil P sorption capacity (Langmuir sorption isotherm) \\
\hline $\mathrm{P}_{\text {prim }}$ & $\mathrm{kg} \mathrm{P} \mathrm{kg}^{-1}$ soil & P-containing primary mineral pool in the mineral soil layers \\
\hline $\mathrm{P}_{\text {solu }}$ & $\mathrm{kg} \mathrm{P} \mathrm{m}^{-3}$ solution & Soil solution P pool \\
\hline $\mathrm{P}_{\text {stab }}$ & $\mathrm{kg} \mathrm{P} \mathrm{kg}^{-1}$ soil & Stable $P$ pool in the mineral soil layers \\
\hline $\mathrm{q}_{\mathrm{r}-\mathrm{sh}}$ & dimensionless & Ratio of coarse root to shoot growth \\
\hline $\mathrm{q}_{r-s h, \max }$ & dimensionless & Maximum ratio of root to shoot growth under nutrient limitation \\
\hline $\mathrm{q}_{\mathrm{r}-\mathrm{s} h, \mathrm{nhrom}}$ & dimensionless & Ratio of root to shoot growth in absence of element deficiency \\
\hline & 1 & Water content of soil layer $i$ \\
\hline $\mathrm{R}_{\text {con,pool }}$ & $\operatorname{kgC~} \mathrm{kg} \mathrm{C}^{-1}$ & Construction respiration rate per unit growth of a tissue pool \\
\hline $\mathrm{r}_{\text {crown }}$ & $\mathrm{m}$ & Tree canopy radius \\
\hline$r_{p o o l}$ & $\mathrm{~m}$ & Average fine root or mycorrhizae radius \\
\hline $\mathrm{R}_{s-p o o l, X}$ & $\mathrm{~m}^{2}$ & Soil to absorption surface resistance \\
\hline $\mathrm{S}_{s(i)}$ & $\mathrm{m}^{2}$ & Surface of rooted area of soil layer $i$ \\
\hline $\mathrm{U}_{A, f(i)}$ & $\mathrm{m}^{2}$ & Average fine root absorption surface in soil layer $i$ \\
\hline $\mathrm{U}_{A, m y c(i)}$ & $\mathrm{m}^{2}$ & Average mycorrhizae absorption surface in soil layer $i$ \\
\hline $\mathrm{W}_{\text {up(i) }}$ & $\mathrm{kg} \mathrm{H}_{2} \mathrm{O}$ & Tree water uptake \\
\hline $\mathrm{x}$ & $\mathrm{m}$ & Average hypha extension from root tip \\
\hline$\hat{X}_{\text {dem }}$ & $\operatorname{kg~X}$ & Tree nutrient demand \\
\hline $\mathrm{X}_{\text {lit,pool }}$ & $\operatorname{kgX}$ & Element amount lost from each tissue pool through litterfall \\
\hline $\mathrm{X}_{\text {myc, res }}$ & $\operatorname{kg} X$ & Mycorrhizal reserve pool content \\
\hline $\mathrm{X}_{\text {myc,struct(i) }}$ & $\operatorname{kgX}$ & Mycorrhizal structural pools content in layer $i$ \\
\hline $\mathrm{X}_{p(i)}$ & $\operatorname{kgX}$ & Dissolved amount in layer $i$ \\
\hline $\mathrm{X}_{\text {pool }}$ & $\operatorname{kg} X$ & Element content of a tissue pool \\
\hline $\mathrm{X}_{\text {req, } T}$ & $\operatorname{kg} X$ & Total tree nutrient requirement \\
\hline $\mathrm{X}_{\text {res }}$ & $\operatorname{kg} X$ & Actual content of tree reserve pool \\
\hline $\mathrm{X}_{\text {res, } \max }$ & $\operatorname{kgX}$ & Maximum content of tree reserve pool \\
\hline $\mathrm{X}_{\text {rettran_in,pool }}$ & $\operatorname{kgX}$ & Element amount retranslocated before and allocated to the reserve pool \\
\hline $\mathrm{X}_{\text {tem }}$ & $\operatorname{kgX}$ & Amount remobilized from internal reserves tissue pools \\
\hline$X_{\text {trans }}$ & $\operatorname{kgX}$ & Nutrient transfer from mycorrhizae to trees \\
\hline $\mathrm{X}_{\text {upp,ffidifii) }}$ & $\operatorname{kg} X$ & Uptake through diffusion by fine roots in soil layer $i$ \\
\hline$X_{\text {upp,firsol(i) }}$ & $\operatorname{kg} X$ & Uptake through water absorption by fine roots in soil layer $i$ \\
\hline $\mathrm{X}_{\text {up }, \text { mycti }(i)}$ & $\operatorname{kgX}$ & Uptake through diffusion by mycorrhizae in soil layer $i$ \\
\hline $\mathrm{X}_{u p, T}$ & $\operatorname{kgX}$ & Total tree element uptake \\
\hline$\theta_{s(i)}$ & $\mathrm{kg} \mathrm{H}_{2} \mathrm{O}$ & Water content in layer $i$ \\
\hline$\rho_{\text {pool }}$ & $\mathrm{kgCm}^{-3}$ & Average fine root or mycorrhizae density \\
\hline
\end{tabular}


Table A2. Parameter values for P and EM modules.

\begin{tabular}{|c|c|c|}
\hline Parameter & Unit & Value \\
\hline CP ratio & - & 1400 \\
\hline Hyphal radius & $\mu \mathrm{m}$ & 10 \\
\hline Mycelial extension $x$ & $\mathrm{~m}$ & 0.05 \\
\hline EMM fraction & - & 0.5 \\
\hline Rhizomorph Fraction & - & 0.3 \\
\hline CN ratio rhizomorph & - & 200 \\
\hline CN ratio EMM & - & 10 \\
\hline CN roottip & - & 10 \\
\hline Turnover Rhizomorphs & days & 450 \\
\hline Turnover EEM & days & 20 \\
\hline Turnover roottip & days & 150 \\
\hline$K_{p i}$ & - & 0.1 \\
\hline Langmuir & - & 1 \\
\hline$P_{\max }$ & - & 400 \\
\hline [P]opt, stem0 & mgP: $g C$ & 0.176 \\
\hline$[P]$ opt,stem1 & - & 0.143 \\
\hline [P]opt,stemheart & - & 0.038 \\
\hline [P]opt,stembark & - & 0.92 \\
\hline$[P]$ opt,$I 1$ & - & 2.30 \\
\hline$[P]$ opt, 10 & - & 3.00 \\
\hline$[P]$ opt,cr0 & - & 0.401 \\
\hline [P]opt,cr1 & 一 & 0.1433 \\
\hline [P]opt,crheartwood & 一 & 0.106 \\
\hline [P]opt,brabark & - & 4.048 \\
\hline [P]opt,bra0 & 一 & 0.776 \\
\hline [P]opt,bra1 & 一 & 0.631 \\
\hline [P]opt,braheart & 一 & 0.167 \\
\hline$[P]$ opt,fr & - & 1.24 \\
\hline$X_{\text {retran_in,pool }}$ & - & 0.3 \\
\hline$I_{\max }$ & $\mathrm{mg} \mathrm{s}^{-1}$ & 2.0 \\
\hline$C_{\text {lim }}$ & $\mathrm{mgl}^{-1}$ & 5 \\
\hline$K_{m}$ & - & 0.001 \\
\hline
\end{tabular}

